\title{
Assessment of degradation of agricultural soils arising from brick burning in selected soil profiles
}

\author{
${ }^{1,2 *}$ H. R. Khan; ${ }^{2}$ K. Rahman; ${ }^{3}$ A. J. M. Abdur Rouf; ${ }^{4}$ G. S. Sattar; ${ }^{2}$ Y. Oki; ${ }^{2}$ T. Adachi \\ ${ }^{1}$ Department of Environmental Management Engineering, Faculty of Environmental Science and Technology, Okayama \\ University, Okayama 700-8530, Japan \\ ${ }^{2}$ Department of Soil, Water and Environment, Faculty of Biological Sciences, University of Dhaka, Dhaka 1000, Bangladesh \\ ${ }^{3}$ Ministry of Science and Information and Communication Technology, Bangladesh Secretariat, Dhaka 1000, Bangladesh \\ ${ }^{4}$ Department of Geology and Mining, University of Rajshahi 6205, Bangladesh
}

Received 8 June 2007; revised 1 July 2007; accepted 27 August 2007; available online 1 September 2007

\begin{abstract}
The study was conducted with the selected soil profile of burnt (soil around brick kilns) and unburnt (agricultural land) soils in the Dinajpur, Rangpur, Rajshahi, Khulna and Patuakhali districts at the western part of Bangladesh to evaluate the effects of brick kilns on soil degradation and environmental pollution. The $\mathrm{pH}$ values of the unburnt soils increased as a function of the soil depth for Rangpur, Khulna and Patuakhali, while decreased for the soil profiles in Dinajpur. Burning of soils significantly $(\mathrm{p}<0.05)$ decreased the average $\mathrm{pH}$ values of soils by $0.4 \mathrm{pH}$ units ( $7 \%$ increased over average content = IOAC), but strikingly increased the average EC values from 0.26 to $1.77 \mathrm{mS} / \mathrm{cm}$ (592 \% IOAC) and the effect was pronounced with the depth function. The average sand content of the soil profiles increased by $330 \%$, while the silt and clay contents decreased by 49 and $40 \%$, respectively. The average losses arising from the burning of agricultural soils were amounted to $63 \%$ for organic matter, 56 to $86 \%$ and 23 to $88 \%$ for available and total N, P, K and S, respectively. This huge loss through the burning of $1 \mathrm{~m}$ deep soil profile, i.e. almost $3 / 4^{\text {th }}$ of the deterioration of soil fertility is not only reducing the crop production but also polluting the associated environment and atmosphere. The burning of enormous $\mathrm{C}, \mathrm{N}$ and $\mathrm{S}$ not only degrade the agricultural soils but also contributing to the changes in the global climate.
\end{abstract}

Key words: Brick kilns, environmental pollution, global climate, soil degradation

\section{INTRODUCTION}

Indigenous soil knowledge, concerns about environmental quality, wise and economic uses of water and soils-the Mother Earth are very essential for longterm protection of our soil and water resources (Warkentin, 2002; Ekosse, et al., 2006). The increasing world's population will put pressure on soil resources. The role of soils, their contribution, and efficient maintenance regarding the quality of nature are undoubtedly important and will increase in the future. Land degradation can be considered in terms of the loss of actual or potential productivity or utility as a result of natural or anthropic factors (Eswaran, 1999). Soil degradation and environmental pollution is one of the most serious problems in the world today, because of their adverse effects on agriculture and the life on Earth. Three quarters of the world soil degradation occur in tropical areas and about $7 \%$ of the total land area (13,

× ${ }^{*}$ Corresponding Author Email: hrkhan@cc.okayama-u.ac.jp Tel./Fax: +8186 2518993
$391 \mathrm{~km}^{2}$ ) of Bangladesh is experiencing land degradation (Eswaran, et al., 1993) where the loss through brick kilns was not considered. Brick kiln is one of the principal agents of topsoil degradation and environmental pollution. Brick kilns are destroying large areas of lands every year especially in Bangladesh where bricks are made by collecting soils from a depth of about 1 to $2 \mathrm{~m}$ in agricultural land which extended over about 5000 ha during the 1998-99 period in different pockets of brick fields (Rahman and Khan, 2001). These affected areas are expanding rapidly due to the increase in brick production. Brick burning not only alters the physicochemical properties and habitats of the nearby soils but also contributing to the pollution of environments and ecosystems. The topsoil nutrient elements and soil biota are destroyed through brick burning. Brick burning are largely influencing the concentrations of greenhouse gases in the atmosphere and it is essential to investigate 
the contribution of soils to the release and/or fixation of greenhouse gases (IUSS, 2002). However, studies on these aspects are scanty and the inhabitants of urban areas, who have been adversely affected by brick manufacturing, are urgently seeking ways and methods to prevent topsoil degradation and preserve the environment. Brick kilns also have significance influence on biodiversity, biogeochemical cycling. Accordingly, this study was conducted to evaluate impacts of brick burning on the degradation of agricultural soils and environmental pollution arising from different soil under variable climatic conditions in the western region of Bangladesh.

\section{MATERIALS AND METHODS}

The assessment of the impact of brick burning on the degradation of agricultural topsoils were carried out for five agroecological zones in the western regions of Bangladesh, including Dinajpur, Rangpur, Rajshahi, Khulna and Patuakhali districts (Fig. 1). The sites were selected based on the climatic conditions, soil type and fertility status, geographic position and land use (Table 1). Five man-made profiles of burnt soil obtained by staking the soils in open air at the boundary or periphery of brick kilns were studied. They consisted of remnants in the brickfields and had been subjected to heating at 400 to $1000{ }^{\circ} \mathrm{C}$ temperatures. The studied five unburnt soils profiles nearby the boundary of the above mentioned brick kilns consisted mostly soils in agricultural lands from where the topsoils (1 to $2 \mathrm{~m}$ depth) had been removed, depending on soil quality, for brick production. The studies were carried out during the dry seasons of 1998 to 1999. A total of ten pits approximately $1.5 \mathrm{~m}$ deep were dug for burnt and unburnt natural soils at a distance of about $0.5 \mathrm{~km}$ from the brick kilns where the topsoils had usually been collected. From the agronomic point of view, the topsoils to a depth of 100 $\mathrm{cm}$ are very important in terms of nutrient dynamics and degradation of soil fertility. Accordingly, the soils in each profile were sampled and analyzed at intervals of $10 \mathrm{~cm}$ to a depth of $100 \mathrm{~cm}$. The representative data obtained from the soils at selected depths and the weight of the topsoils ( 1 m extending over an area of 5,000 ha, topsoil sampling areas) were considered for the determinations of nutrients. The bulk samples obtained from each section were stored in the field moist conditions by putting the soil samples into polyethylene bags in an airtight box immediately prior to laboratory analysis. The subsamples were air-dried and gently crushed to pass through 1 and $2 \mathrm{~mm}$ mesh sieves, as required. After treatment with $300 \mathrm{~g} / \mathrm{kg} \mathrm{H}_{2} \mathrm{O}_{2}$, particle size distribution was determined by the pipette method (Day, 1965). Textural classes were determined using a triangular coordinate diagram. The $\mathrm{pH}$ of the soil samples was determined in the laboratory (dry soil and distilled water ratio of 1: 2.5) and measured by using a Corning glass electrode pH meter (Jackson, 1973). Electrical conductivity (EC) of the soils was determined at a ratio of soil: water $=1$ : 5 according to the method of Richards (1954). Organic carbon content of the soil samples was determined volumetrically by the wet oxidation method with a $1 \mathrm{~N} \mathrm{~K}_{2} \mathrm{Cr}_{2} \mathrm{O}_{7}$ solution and concentrated $\mathrm{H}_{2} \mathrm{SO}_{4}$ mixture, followed by rapid titration with a $1 \mathrm{~N} \mathrm{FeSO}_{4}$ solution, as recommended by Nelson and Sommers (1982). Organic matter content of the soil samples was estimated by multiplying the percentage of organic carbon using the conventional Van Bemmelen's factor of 1.724 . Available nitrogen was extracted with a $2 \mathrm{M} \mathrm{KCl}$ solution and the amount was determined according to the Micro-Kjeldahl distillation method (Jackson, 1973). Available Pin soil was extracted with a $0.5 \mathrm{M} \mathrm{NaHCO}_{3}$, as recommended by Olsen, et al., (1954) and the amount was determined with a spectrophotometer after the development of a blue color using ascorbic acid and potassium antimony tartrate as reagents. Available S was extracted with a $500 \mathrm{mg} \mathrm{P} / \mathrm{kg}$ solution of $\mathrm{Ca}\left(\mathrm{H}_{2} \mathrm{PO}_{4}\right)$ and the amount was determined with a spectrophotometer after the development of turbidity with $\mathrm{BaCl}_{2}$ using Tween-80 as the suspending agent of sulfate precipitation (Klute, 1986). Total N content in soil was determined by the Micro Kjeldahl method following $\mathrm{H}_{2} \mathrm{SO}_{4}$ acid digestion and alkali distillation (Jackson, 1973). Total P, K and S contents were determined by digestion with a mixture of concentrated $\mathrm{HCl} / \mathrm{HNO}_{3}(1: 3)$, as described by Schlichting and Blume (1966). Total P content was determined by the yellow color method (Jackson, 1973), S content was determined after the development of turbidity (Klute, 1986) and the total $\mathrm{K}$ content was measured with a flame photometer (Klute, 1986). Correlations between the selected parameters, level of significance and standard deviation were determined using statistical packages in Office 2003 Program.

\section{RESULTS}

\section{Sites and soil conditions}

The total land area of Bangladesh has been divided into 30 agroecological zones (AEZ), which provides 


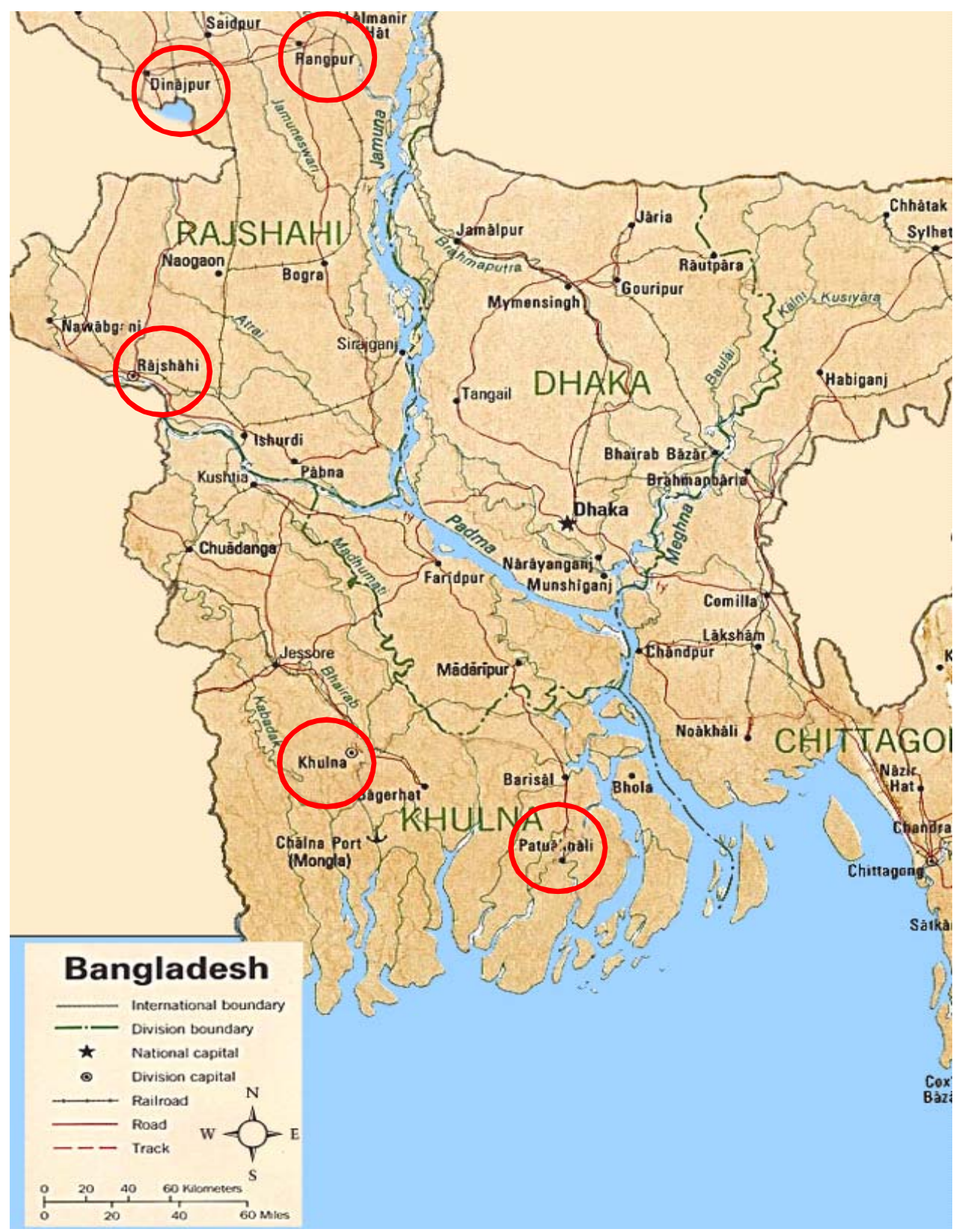

Fig. 1: Map of the study area (sites are circled) in Bangladesh

extended national, district and thana digitized databases related to soil/land types, climatic conditions, hydrology, crops, land use and crop suitability as well as computerized procedures for land productivity assessment and mapping, demographic and socioeconomic information. Detailed information about the individual AEZs can be obtained from FAO website.
The present study sites in the five agro-ecological zones exhibited average rainfall values ranging from 1300 to more than $3000 \mathrm{~mm}$ and temperatures ranging from less than $20^{\circ} \mathrm{C}$ to more than $40^{\circ} \mathrm{C}$, and differed in the soil types, soil fertility and land use conditions (Table 1). The study site at Puthia in Rajshahi had the lowest average rainfall (1300-1400 mm) and the longest 
Assessment of degradation of agricultural soils arising from brick burning...

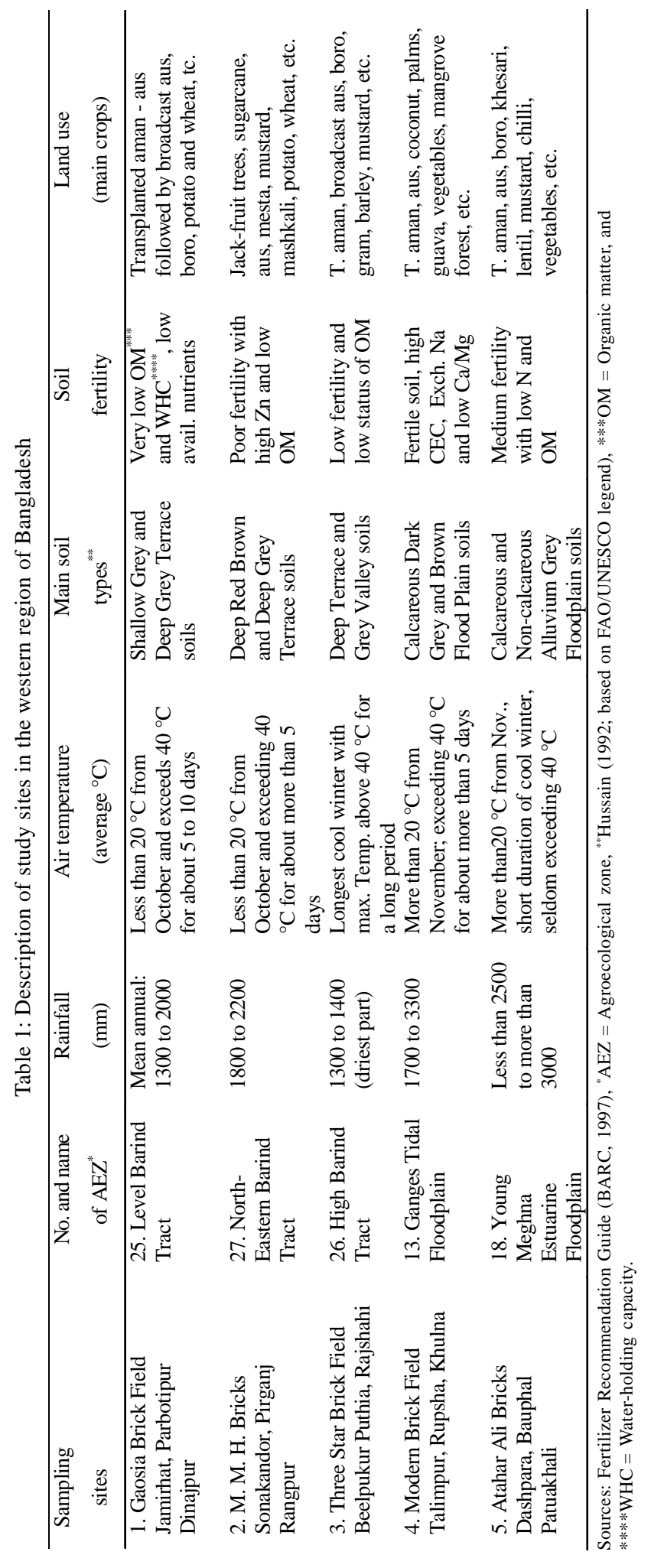


cool winter with maximum temperature above $40^{\circ} \mathrm{C}$ for a long period not only among the study sites but also all over Bangladesh. This was the driest area in Bangladesh. The study sites at Parbotipur in Dinajpur and at Pirganj in Rangpur were also affected by the high temperature and low rainfall. The site at Bauphal in Patuakhali was observed very moist condition among the study sites followed by Khulna. Ten general soil types (Hussain, 1992: based on FAO/UNESCO legend) predominated in the selected five AEZs (BARC, 1997), where the soils are poor to fertile. The soils at Rupsha in Khulna was relatively more fertile, followed by the soils at Bauphal in Patuakhali and the soils with poor fertility were identified at Pirganj in Rangpur, preceded by the sites at Dinajpur and Rajshahi (Table 1). Cropping patterns and types of crops are also quite different in the study sites depending on the geography, climate, and land position (Table 1).

\section{Distribution of soil properties}

The $\mathrm{pH}$ values in the burnt and unburnt soil profiles ranged from 5.0 to 6.2 (burnt) and 5.0 to 5.5 (unburnt) for Dinajpur, 4.4 to 5.1 and 4.9 to 6.4 for Rangpur, 6.8 to 7.6 and 7.7 to 7.9 for Rajshahi, 7.4 to 8.1 and 7.7 to 8.1 for Khulna, and 6.9 to 7.5 and 7.8 to 8.0 for Patuakhali (Table 2). The $\mathrm{pH}$ values in the profiles of the unburnt soils increased with increasing depths, except for the soil profile in Dinajpur, where the trend of $\mathrm{pH}$ distribution was opposite and no pronounced change was observed in the unburnt soil profile in Rajshahi (Table 2). Soil burning was found to decrease the average $\mathrm{pH}$ values of soils with the depth function (Table 3) and in the present study; the decrement in $\mathrm{pH}$ was by $0.4 \mathrm{pH}$ units (7\% increased over average content). The EC values of all the profiles of unburnt soils decreased with depth and showed reverse trend in EC values due to burning of the soils, except for the soils in Rangpur (Table 2). The increment of average EC values was from 0.26 to $1.77 \mathrm{mS} / \mathrm{cm}$, i.e. $592 \%$ IOAC (Table 3). Sand content of all the soils increased by $330 \%$, while silt and clay contents decreased by 49 and $40 \%$, respectively (Table 3).

\section{Losses of nutrients}

The content of organic matter was higher in the unburnt soils in Patuakhali (1.61\%) followed by Khulna $(1.52 \%)$ and the lowest amount of organic matter was obtained from the soils in Rajshahi (1.17\%: Table 2). The statuses of nutrients showed almost similar trends of distribution as that of organic matter. The average loss of these valuable soil components due to burning of the agricultural topsoils amounted to $63 \%$ for soil organic matter, 56 to $86 \%$ and 23 to $88 \%$ for available and total N, P, K and S, respectively. The distribution of organic matter, total and available N, S and total P in the unburnt soil profiles showed significant $(\mathrm{p} \leq 0.05)$ negative relationships with the corresponding depths of soils, though the total $\mathrm{K}$ in the unburnt soils showed a significant positive relationship (Table 4). The trend of the relationships of these components was very similar to that in the burnt soils but not significant (Table 4). Soil organic matter showed a significant positive relationship with the contents of the nutrients in the unburnt soils, while these relationships were not significant for the burnt soils, except for the total S content (Table 4). The available $\mathrm{N}$ was found to have a significant positive relationship with the nutrient contents in both the burnt and unburnt soils but no significant relationship was observed for P. The trends of the relationships among the components studied in both the burnt and unburnt soils were very similar with a few exceptions (Table 4).

\section{DISCUSSION AND CONCLUSION}

The profile of the studied unburnt agricultural soil up to $1 \mathrm{~m}$ depth in Khulna followed by Patuakhali and Rajshahi were slightly alkaline, while the soils in Dinajpur and Rangpur were strongly to medium acid (Donahue, et al., 1987). This categorization of the soils can be used for proper crop production and planning in the studied areas. Soil burning was found to decrease the $\mathrm{pH}$ values of soils by $0.4 \mathrm{pH}$ units (about 7\%), while the increment of EC value was striking (increased from 0.26 to $1.77 \mathrm{mS} / \mathrm{cm}$, about $592 \%$ IOAC) due to burning of salts/nutrients in the soils. The increment of sand content in the burnt soils was attributed to the addition of more sandy soils materials during brick production which may lead to the reduction of the strength and quality of bricks. The $3 / 4^{\text {th }}$ loss of organic matter and nutrients in the burnt soils were due to the burning of the agricultural topsoils. It is well known that soil organic matter is a reservoir for plant nutrients, enhances water holding capacity, protects soil structure against compaction and erosion, and thus determines soil productivity. All agriculture to some extend depends on the content of soil organic matter as well as the soil nutrients. Maintenance of organic matter is critical for preventing land degradation 
H. R. Khan, et al.

Table 2: Some selected properties of burnt and unburnt soils sampled from soil profiles (1 $\mathrm{m}$ depth) in the western region of Bangladesh

\begin{tabular}{|c|c|c|c|c|c|c|c|c|c|c|c|c|c|}
\hline \multirow{2}{*}{ Location } & \multirow{2}{*}{$\begin{array}{l}\text { Depth } \\
(\mathrm{cm})\end{array}$} & \multirow[t]{2}{*}{$\mathrm{pH}$} & \multirow{2}{*}{$\begin{array}{c}\mathrm{EC} \\
(\mathrm{mS} / \mathrm{cm})\end{array}$} & \multirow{2}{*}{$\begin{array}{l}\text { Tex- } \\
\text { ture }^{\dagger}\end{array}$} & \multirow{2}{*}{$\begin{array}{l}\mathrm{OM} \\
(\%)\end{array}$} & \multicolumn{4}{|c|}{ Avail. nutrient (mg/kg) } & \multicolumn{4}{|c|}{ Total content (\%) } \\
\hline & & & & & & $\mathrm{N}$ & $\mathrm{P}$ & $\mathrm{K}$ & $\mathrm{S}$ & $\mathrm{N}$ & $\mathrm{P}$ & $\mathrm{K}$ & $\mathrm{S}$ \\
\hline \multicolumn{14}{|c|}{ Burnt soils: } \\
\hline \multirow[t]{4}{*}{ 1. Dinajpur } & 10 & 5.2 & 0.25 & SL & 0.53 & 9 & 0.54 & 39 & 9 & 0.04 & 0.006 & 1.07 & 0.007 \\
\hline & 20 & 5.0 & 0.26 & SL & 0.47 & 7 & 0.51 & 34 & 8 & 0.04 & 0.008 & 1.12 & 0.006 \\
\hline & 30 & 5.5 & 2.25 & SL & 0.62 & 9 & 0.47 & 31 & 7 & 0.03 & 0.006 & 0.98 & 0.006 \\
\hline & 60 & 6.2 & 2.70 & SL & 0.50 & 6 & 0.43 & 29 & 7 & 0.04 & 0.005 & 1.05 & 0.005 \\
\hline \multirow{4}{*}{ 2. Rangpur } & 20 & 4.6 & 1.18 & SL & 0.38 & 6 & 0.46 & 37 & 6 & 0.03 & 0.008 & 1.44 & 0.008 \\
\hline & 30 & 4.9 & 1.05 & $\mathrm{~L}$ & 0.38 & 7 & 0.41 & 36 & 8 & 0.04 & 0.006 & 1.32 & 0.007 \\
\hline & 60 & 5.0 & 1.45 & SiCL & 0.55 & 8 & 0.38 & 39 & 6 & 0.03 & 0.005 & 1.21 & 0.004 \\
\hline & 100 & 5.1 & 1.10 & CL & 0.62 & 5 & 0.33 & 27 & 5 & 0.03 & 0.005 & 1.22 & 0.004 \\
\hline 3. Rajshahi & 10 & 6.8 & 2.60 & SCL & 0.34 & 10 & 0.31 & 51 & 9 & 0.04 & 0.009 & 1.12 & 0.006 \\
\hline \multirow{5}{*}{ 4. Khulna } & 10 & 7.6 & 1.05 & SCL & 0.53 & 15 & 0.3 & 61 & 12 & 0.05 & 0.011 & 0.91 & 0.008 \\
\hline & 20 & 7.4 & 1.08 & SCL & 0.50 & 17 & 0.3 & 67 & 11 & 0.06 & 0.010 & 0.92 & 0.008 \\
\hline & 30 & 7.5 & 2.10 & $\mathrm{~L}$ & 0.43 & 18 & 0.3 & 56 & 8 & 0.05 & 0.091 & 0.87 & 0.006 \\
\hline & 60 & 7.5 & 2.20 & SL & 0.48 & 17 & 0.3 & 48 & 11 & 0.04 & 0.007 & 0.79 & 0.006 \\
\hline & 100 & 8.1 & 0.25 & LS & 0.57 & 11 & 0.2 & 43 & 9 & 0.04 & 0.005 & 0.74 & 0.007 \\
\hline \multirow[t]{5}{*}{ 5. Patuakhali } & 10 & 7.1 & 2.45 & $\mathrm{~L}$ & 0.60 & 17 & 0.4 & 55 & 11 & 0.04 & 0.009 & 1.33 & 0.007 \\
\hline & 20 & 7.0 & 2.38 & $\mathrm{~L}$ & 0.55 & 15 & 0.4 & 61 & 10 & 0.05 & 0.008 & 1.25 & 0.006 \\
\hline & 30 & 6.9 & 2.75 & SL & 0.47 & 16 & 0.3 & 56 & 13 & 0.04 & 0.008 & 1.14 & 0.005 \\
\hline & 60 & 7.3 & 2.25 & CL & 0.45 & 16 & 0.3 & 43 & 9 & 0.03 & 0.005 & 1.17 & 0.007 \\
\hline & 100 & 7.5 & 0.95 & CL & 0.50 & 12 & 0.3 & 38 & 8 & 0.03 & 0.004 & 1.09 & 0.008 \\
\hline & 20 & 5.6 & 0.20 & SiCL & 1.57 & 32 & 3 & 205 & 19 & 0.07 & 0.04 & 1.98 & 0.060 \\
\hline & 30 & 6.0 & 0.15 & SiCL & 1.36 & 20 & 3 & 203 & 16 & 0.06 & 0.03 & 1.79 & 0.060 \\
\hline & 60 & 6.4 & 0.05 & SiCL & 1.03 & 14 & 3 & 212 & 17 & 0.06 & 0.03 & 1.80 & 0.060 \\
\hline & 100 & 6.4 & 0.05 & CL & 0.71 & 16 & 2 & 198 & 13 & 0.05 & 0.04 & 1.28 & 0.040 \\
\hline 3. Rajshahi & 10 & 7.8 & 0.50 & SiCL & 1.64 & 38 & 2 & 228 & 20 & 0.07 & 0.02 & 1.82 & 0.060 \\
\hline & 20 & 7.9 & 0.25 & SiCL & 1.38 & 25 & 3 & 226 & 15 & 0.06 & 0.02 & 1.78 & 0.050 \\
\hline & 30 & 7.7 & 0.20 & $\mathrm{SiC}$ & 1.17 & 18 & 2 & 203 & 14 & 0.04 & 0.01 & 1.45 & 0.040 \\
\hline & 60 & 7.8 & 0.15 & $\mathrm{SiC}$ & 1.02 & 10 & 2 & 201 & 15 & 0.03 & 0.01 & 1.30 & 0.040 \\
\hline & 100 & 7.7 & 0.15 & $\mathrm{SiC}$ & 0.62 & 14 & 2 & 192 & 12 & 0.02 & 0.01 & 0.72 & 0.030 \\
\hline 4. Khulna & 10 & 7.7 & 1.10 & SiL & 2.41 & 53 & 3 & 430 & 21 & 0.12 & 0.05 & 1.20 & 0.080 \\
\hline & 20 & 8.0 & 0.30 & SiCL & 1.55 & 40 & 2 & 423 & 20 & 0.09 & 0.04 & 1.23 & 0.080 \\
\hline & 30 & 8.1 & 0.25 & SiCL & 1.45 & 31 & 2 & 420 & 14 & 0.08 & 0.03 & 1.32 & 0.070 \\
\hline & 60 & 8.0 & 0.35 & SiCL & 1.33 & 22 & 2 & 427 & 12 & 0.05 & 0.03 & 1.32 & 0.060 \\
\hline & 100 & 8.1 & 0.40 & $\mathrm{SiC}$ & 0.84 & 14 & 2 & 388 & 12 & 0.03 & 0.02 & 1.60 & 0.050 \\
\hline 5. Patuakhali & 10 & 7.8 & 0.40 & SiCL & 2.38 & 51 & 3 & 314 & 22 & 0.09 & 0.04 & 1.51 & 0.040 \\
\hline & 20 & 7.9 & 0.20 & SiCL & 1.60 & 42 & 3 & 311 & 19 & 0.08 & 0.03 & 1.62 & 0.040 \\
\hline & 30 & 8.0 & 0.25 & $\mathrm{~S}$ & 1.66 & 30 & 2 & 308 & 18 & 0.07 & 0.03 & 1.43 & 0.050 \\
\hline & 60 & 8.0 & 0.25 & SiL & 1.50 & 21 & 2 & 295 & 20 & 0.07 & 0.04 & 1.34 & 0.050 \\
\hline & 100 & 8.0 & 0.20 & SiL & 0.93 & 13 & 2 & 286 & 16 & 0.05 & 0.03 & 1.07 & 0.030 \\
\hline
\end{tabular}

$\dagger$ Texture: SL = Sandy Loam, SCL =Sandy Clay Loam, L = Loam, CL = Clay Loam, LS = Loamy Sand, C = Clay, SiL = Silt Loam, SiCL = Silty Clay Loam, $\mathrm{SiC}=$ Silty Clay, and S = Silt 
Int. J. Environ. Sci. Tech., 4 (4): 471-480, Autumn 2007

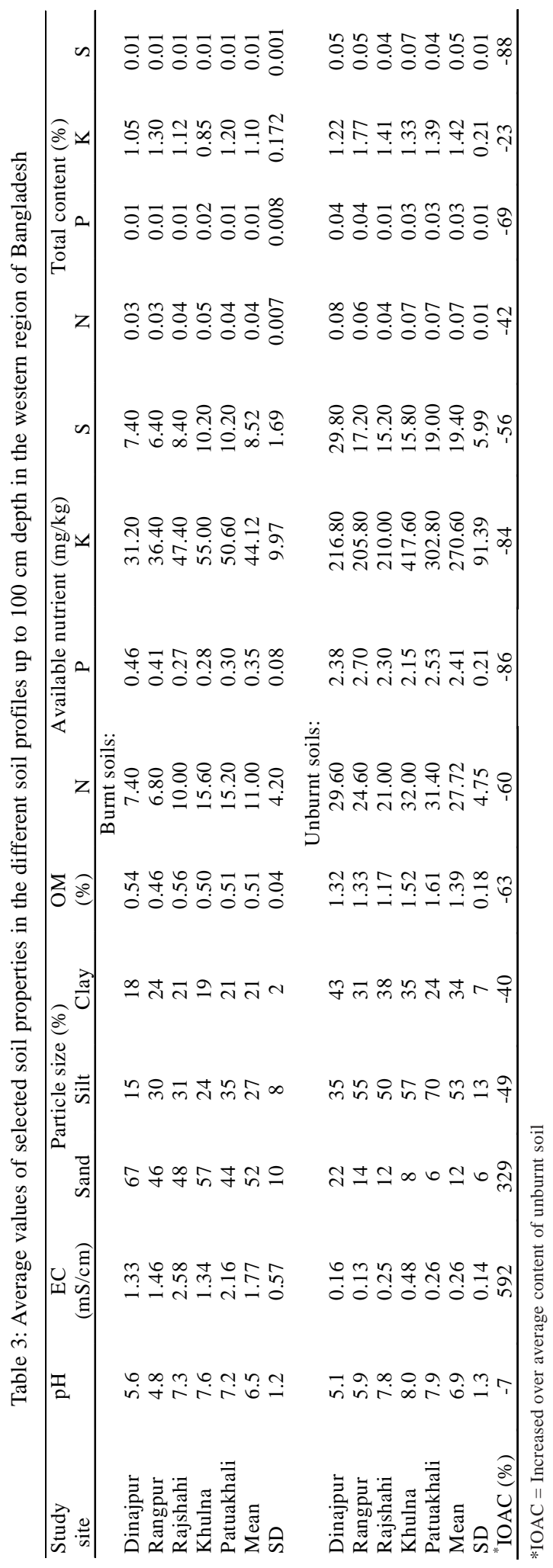




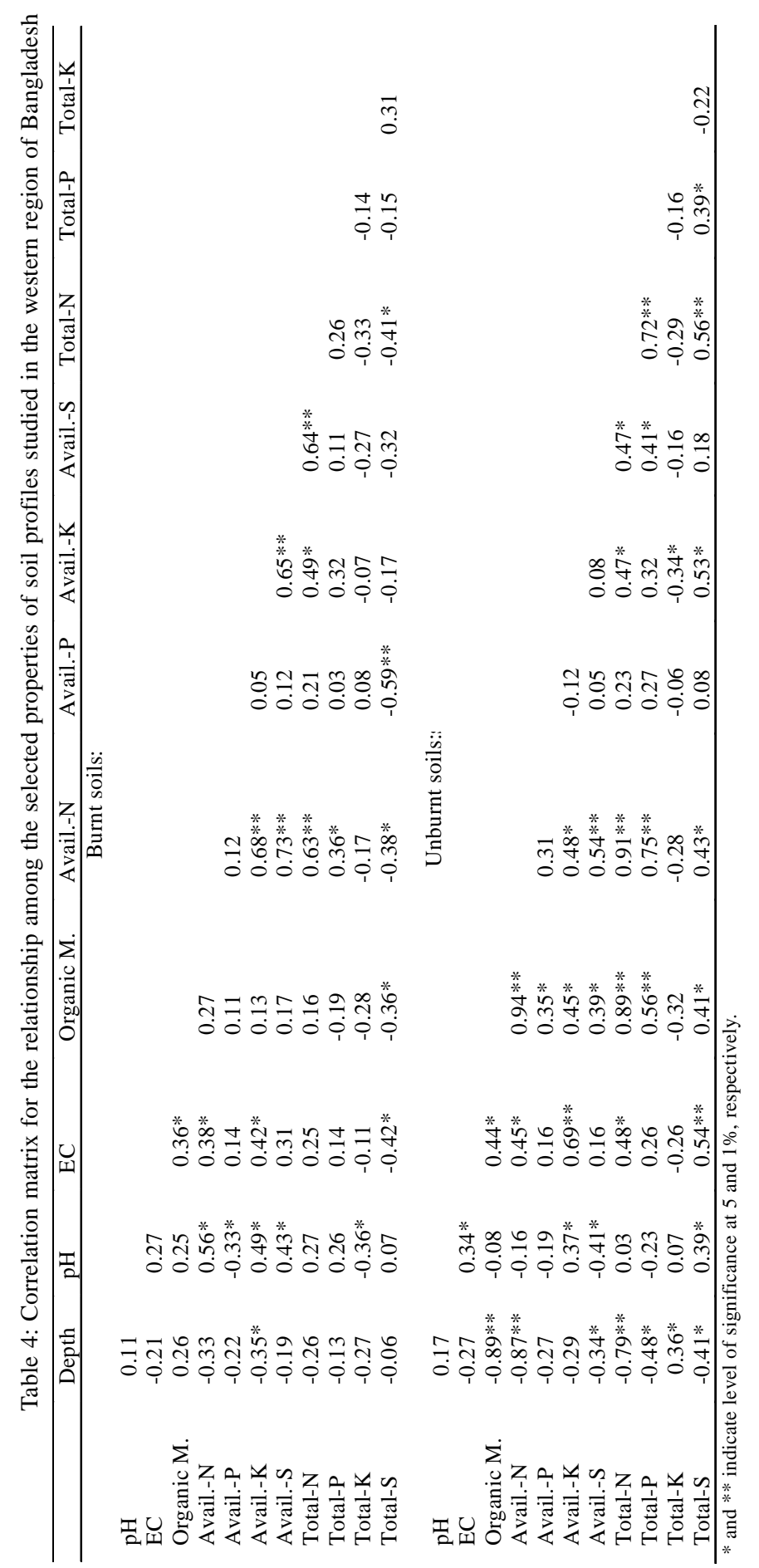


(Martius, et al., 2001). Soil organic matter showed a significant positive relationship with the contents of the nutrients in the unburnt soils, while these relationships were not significant for the burnt soils. These relationships revealed that the burning of topsoils seriously degraded the soil fertility, productivity and sustainability level of the environments. This huge loss of nutrients associated the burning of topsoils, i.e. almost $3 / 4^{\text {th }}$ of the deterioration of soil fertility has not only reduced the crop production but also led to pollution of the environment and atmosphere. The losses by burning of the three-fourth quarter of organic matter, total $\mathrm{N}$ and total $\mathrm{S}$ throughout the $1 \mathrm{~m}$ deep profile over an area of 5000 ha, led to a large depletion of nutrients from the soils and also adversely affected the environment, along with contribution to changes in the global climate. Therefore, the losses of the topsoil by brick burning are a serious disturbance for the society and habitat, and would be detrimental to the functioning of relevant ecosystem, environment and atmosphere. The present investigation insight us in increasing awareness about the status of soil degradation and environmental pollution induced by the burning of topsoils through brick kilns. Losses of organic matter, N, P, K and S of the topsoil amounted to about $3 / 4^{\text {th }}$ parts through brick burning. The huge loss of $\mathrm{C}, \mathrm{N}$ and $\mathrm{S}$ were not only reducing crop production and soil biota but also polluting the associated environment and contributing to changes in the global climate. Dust, high temperatures $\left(400\right.$ to $1000^{\circ} \mathrm{C}$ ) and unhygienic conditions of living of workers create hazards to survival of the local habitats. The present findings suggested that the brick producers should strictly follow the rules restricting the use of agricultural topsoils for brick production. They can also adopt suitable international technology to produce bricks or blocks with a good quality, as practiced in the developed countries, through the use of alluvial clay and cement or black cotton and lateritic clay (NRDC, 2001). Soil degradation and environmental pollution are not inevitable and can be controlled if major abuses are avoided and improved methods of environmental management are developed.

\section{ACKNOWLEDGEMENTS}

The research was funded by the Ministry of Science and Information and Communication Technology,
Government of Bangladesh. The authors are grateful to the Alexander von Humboldt Foundation in Germany for their instrumental support. They are also grateful to the project staffs and technicians of the Department of Soil, Water and Environment, University of Dhaka, Bangladesh for their generous support to complete this research work.

\section{REFERENCES}

BARC, (1997). Fertilizer Recommendation Guide. Publ. BARC, Farm gate, Bangladesh Agriculture Research Council Tejgaon, Dhaka, Bangladesh. 196.

Day, P.R., (1965). Particle fractionation and particle size analysis. In Methods of Soil Analysis. Part 2 (Ed.) C. A. Black, Agron. Series 9. Am. Soc. Agron., Publ. Madison, WI, USA. 545566.

Donahue, R.L.; Miller, R.W.; Shickluna, J.C.; (1987). Soils: An

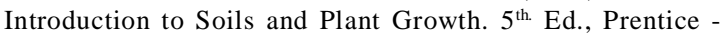
Hall of India Pvt. Ltd., New Delhi - 110001, India. 667.

Ekosse, G.I.E.; Fouche, P.S.; Mashatola, B., (2006). Total organic carbon in soils and its relation with manganese concentrations in soils and vegetation close to an abandoned manganese mine. Int. J. Environ. Sci. Tech., 3 (1), 15-24.

Eswaran, H., (1999). Recommendation in the proceedings of the $2^{\text {nd }}$ international conference on land degradation. January 25-29, Khon Kaen, Thailand. 9.

Eswaran, H.; Virmani, S.M.; Spivey Jr.L.D., (1993). Sustainable agriculture in developing countries: constraints, challenges, and choises. In Technologies for Sustainable Agriculture in the Tropics, (Eds.) J. Ragland and R. Lal. ASA Sp. Publ. 56, Madisin, WI. 7-24.

Hussain, M.S., (1992). Soil classification with special reference to the soils of Bangladesh. Publ. Univ. of Dhaka, Dhaka, Bangladesh. 433.

IUSS, (2002). Soil and the environment, IUSS Commission VIII. p. 66. World Congress of Soil Science. International Union of Soil Science, 14-21 August, Thailand.

Jackson, M.L., (1973). Soil Chemical Analysis. Prentic Hall of India Pvt. Ltd., New Delhi. 41-330.

Klute, A., (1986). Methods of Soil Analysis. Agron. Series 9. Am. Soc. Agron. Publ., Madison, WI, USA.

Martius, C.; Tiessen, H.; van Vlek, P.L.G., (2001). Managing organic matter in tropical soils: scope and limitations. Nutr. Cycl. Agroecosys., 61, 1-2.

Nelson, D.W.; Sommers, L.E., (1982). Total carbon, organic carbon and organic matter. In Methods of Soil Analysis. Part 2 ( $2^{\text {nd. }}$ Ed.), Ed. A. L. Page, Agron. Series 9, Am. Soc. Agron., Publ. Madison, WI, USA. 539-579.

NRDC., (2001). Technology offer: Semi-mechanized brick manufacturing plant. National Research Development Corporation: a government of India enterprise 1-3. Availabale on: http://www.nrdcindia.com

Olsen, S.R.; Cale, C.V.; Watanabe, F.S.; Dean, L.A., (1954). Estimation of available phosphorus in soils by extraction with sodium bicarbonate. USDA Circ. 939, Washington, USA.

Rahman, M.K.; Khan, H.R., (2001). Impacts of brick kiln on topsoil degradation and environmental pollution. Project report submitted to the Ministry of Science and Information and Communication Technology, Bangladesh Secretariat (Dhaka). 210. 
Richards, L.A., (1954). Diagnosis and improvement of saline and alkali soils. In USDA Handbook No. 60. US Govt. Print. Office, Washington, USA. 84-156.

Schlichting, E.; Blume, H.P., (1996). Bodenkundliches Praktikum. No. 81. Blackwell Wissenschafts-Verlag, Berlin. 295.
Warkentin, B.P., (2002). Soil and the Environment, Commission VIII. In Bulletin of the International Union of Soil Science, No. 101 for the World Congress of Soil Science. 14-21 August, Thailand. 29-32.

\section{AUTHOR (S) BIOSKETCHES}

Khan, H. R., Ph.D., AvH-Fellow, professor in the Department of Environmental Management Engineering, Faculty of Environmental Science and Technology, Okayama University, Okayama 700-8530, Japan.

Email: hrkhan@cc.okayama-u.ac.jp

Rahman, K., Ph.D., professor in the Department of Soil, Water and Environment, Faculty of Biological Sciences, University of Dhaka, Dhaka 1000, Bangladesh. Email: soil@du.bangla.net

Abdur Rouf, A. J. M., Ph.D., senior section officer in the Ministry of Science and Information \& Communication Technology, Bangladesh Secretariat, Dhaka 1000, Bangladesh. Email: soil@du.bangla.net

Sattar, G. S., associate professor in the Department of Geology and Mining, University of Rajshahi-6205, Bangladesh. Email: duharun@yahoo.com

Oki, Y., Ph.D., professor in the Department of Environmental Management Engineering, Faculty of Environmental Science and Technology, Okayama University, Okayama 700-8530, Japan.

Email: yokooki@cc.okayama-u.ac.jp

Adachi, T., professor in the Department of Environmental Management Engineering, Faculty of Environmental Science and Technology, Okayama University, Okayama 700-8530, Japan.

Email: adachit@cc.okayama-u.ac.jp

This article should be referenced as follows:

Khan, H.R.; Rahman, K.; Abdur Rouf, A.J.M.; Sattar, G.S.; Oki, Y.; Adachi, T., (2007). Assessment of degradation of agricultural soils arising from brick burning in selected soil profiles. Int. J. Environ. Sci. Tech., 4 (4), 471480. 